Title-page

\title{
Tracing sources of ammonium in reducing groundwater in a well field in Hanoi (Vietnam) by means of stable nitrogen isotope $\left(\delta^{15} \mathrm{~N}\right)$ values
}

Jenny Norrman ${ }^{*}$ a,b, Charlotte J. Sparrenbom $c$, Michael Berg d, Dang Duc Nhan e, Gunnar Jacks f, Peter Harms-Ringdahl g, Pham Quy Nhan h, Håkan Rosqvist c

a Division of GeoEngineering, Department of Civil and Environmental Engineering, Chalmers University of Technology, 412 96, Göteborg, Sweden. jenny.norrman@ chalmers.se

b Swedish Geotechnical Institute, Hugo Grauers gata 5 B, 41296 Göteborg, Sweden. jenny.norrman@swedgeo.se

c Department of Geology, Lund University, Sölvegatan 12, 22362 Lund, Sweden. charlotte.sparrenbom@geol.lu.se

d Eawag, Swiss Federal Institute of Aquatic Science and Technology, 8600 Dübendorf, Switzerland. michael.berg@eawag.ch

e Institute of Nuclear Science and Technology, 179 Hoang Quoc Viet, Cau Giay, Hanoi, Viet Nam. dangducnhan50@gmail.com

f International Groundwater Arsenic Research Group, Department of Land and Water Resources Engineering, Royal Institute of Technology, 10044 Stockholm, Sweden. gunnjack@kth.se

g Empirikon Konsult AB, Box 75, 18621 Vallentuna, Sweden. peter.harms-ringdahl@empirikon.se

h Department of Hydrogeology, Hanoi University of Mining and Geology, Dong Ngac, Tu Liem, Hanoi, Viet Nam. phamquynhan@yahoo.com $\left.{ }^{* *}\right)$

i Department of Geology, Lund University, Sölvegatan 12, 22362 Lund, Sweden. hakan.rosqvist@ geol.lu.se

*) Corresponding author: Jenny Norrman, Chalmers University of Technology, Department of Civil and Environmental Engineering, 41296 Göteborg, Sweden. E-mail:

jenny.norrman@ chalmers.se, Phone: +46 317722182

**) Present address: Hanoi University of Natural Resources and Environment, Cau Dien, Tu Liem, Hanoi, Viet Nam.

\section{Highlights}

- Elevated $\mathrm{NH}_{4}{ }^{+}$concentration in groundwater is investigated by $\mathrm{N}$ isotope ratios

- $\delta^{15} \mathrm{~N}$ was measured in the peat layers, in groundwater, and in surface water

- $\mathrm{C} / \mathrm{N}$ ratio, mineralization potential, and exchangeable $\mathrm{NH}_{4}{ }^{+}$was measured in sediments

- Enrichment of $\delta^{15} \mathrm{~N}$ in the groundwater is likely caused by ammonium volatilization

- $\mathrm{NH}_{4}{ }^{+}$originates from sedimentary $\mathrm{OM}$ and wastewater seepage in combination

This document is the accepted manuscript version of the following article: Norrman, J., Sparrenbom, C. J., Berg, M., Dang, D. N., Jacks, G., Harms-Ringdah1, P., ... Rosqvist, H. (2015). Tracing sources of ammonium in reducing groundwater in a well field in Hanoi (Vietnam) by means of stable nitrogen isotope ( $\delta 15 \mathrm{~N}$ ) values. Applied Geochemistry, 61, 248-258. https://doi.org/10.1016/j.apgeochem.2015.06.009

This manuscript version is made available under the CC-BY-NC-ND 4.0

1icense http://creativecommons.org/1icenses/by-nc-nd/4.0/ 


\title{
Tracing sources of ammonium in reducing groundwater in a well field in Hanoi (Vietnam) by means of stable nitrogen isotope $\left(\delta^{15} \mathrm{~N}\right)$ values
}

\begin{abstract}
In the Southern part of Hanoi, high ammonium $\left(\mathrm{NH}_{4}^{+}\right)$concentrations in reducing groundwater have been an issue over the last 25 years. Elevated $\mathrm{NH}_{4}{ }^{+}$concentrations in groundwater, in general, are an indicator of influences from anthropogenic sources, but the buried peat layers in the Red River delta formation are also hypothesized to contribute to the high $\mathrm{NH}_{4}{ }^{+}$levels (up to $100 \mathrm{mg} / \mathrm{L}$ ). We traced the sources of $\mathrm{NH}_{4}{ }^{+}$at the $\mathrm{Nam} \mathrm{Du}$ well field of the Hanoi water works by means of isotope ratios $\left({ }^{15} \mathrm{~N} /{ }^{14} \mathrm{~N}\right)$. The $\delta^{15} \mathrm{~N}$ values were determined for total sedimentary $\mathrm{N}$ and exchangeable $\mathrm{NH}_{4}{ }^{+}$of the peat material, and for $\mathrm{NH}_{4}{ }^{+}$ dissolved in deep and shallow groundwater, sewage, and surface water. Groundwater $\mathrm{NH}_{4}{ }^{+}$of the upper (Holocene) and the lower (Pleistocene) aquifers had higher $\delta^{15} \mathrm{~N}$ values than did total $\mathrm{N}$ and $\mathrm{NH}_{4}{ }^{+}$of the sediments, and were somewhat higher than the $\delta^{15} \mathrm{~N}_{\text {values }}$ of $\mathrm{NH}_{4}{ }^{+}$in sewage and surface water. We conclude that the present conditions of temperature and $\mathrm{pH}$ tend to promote deprotonation of $\mathrm{NH}_{4}{ }^{+}$to ammonia $\left(\mathrm{NH}_{3}\right)$, which eventually degasses from the groundwater table to the unsaturated pore space. This can cause an enrichment of ${ }^{15} \mathrm{~N}$ in the remaining $\mathrm{NH}_{4}{ }^{+}$, as the lighter ${ }^{14} \mathrm{~N}$ in $\mathrm{NH}_{3}$ is volatilized at a slightly faster rate. The intermediate $\delta^{15} \mathrm{~N}$ values within the Pleistocene aquifer can be explained by the recharge thereto, which is a mixture of the high $\delta^{15} \mathrm{~N}$ values of the Holocene aquifer and the low $\delta^{15} \mathrm{~N}$ values of water infiltrating from the Red River into the Pleistocene aquifer. Some part of the increased groundwater $\mathrm{NH}_{4}{ }^{+}$is likely to arise from anthropogenic activities, as supported by several indications: a large drawdown in the Pleistocene aquifer caused by Hanoi's extensive water abstraction and subsequent downward gradient from the upper Holocene aquifer; the presence of coliforms in groundwater; and a positive correlation between ammonium and $\mathrm{DOC}, \mathrm{Cl}, \mathrm{Br}$ and $\mathrm{Ni}$, but a lack of correlation with As. However, the much higher concentrations of $\mathrm{NH}_{4}{ }^{+}$in the groundwater compared to the potential surface sources, the positive correlation between $\mathrm{NH}_{4}{ }^{+}$and DOC, the abundance of natural organic matter (OM), the amount of exchangeable $\mathrm{NH}_{4}{ }^{+}$in the sediments, and the highly reducing conditions in the aquifers indicate that $\mathrm{N}$-mineralization of organic $\mathrm{N}$ from the peat contribute substantially to the high $\mathrm{NH}_{4}{ }^{+}$levels in groundwater of the Nam Du well field.
\end{abstract}

Keywords: Ammonium, $\delta^{15} \mathrm{~N}$, Reducing conditions, Arsenic, Groundwater, Red River delta 


\section{$1 \quad$ Introduction}

A high concentration of ammonium in groundwater is typically associated with contamination by sewage water or with leakage of manure or mineral fertilizer from agricultural activities. The World Health Organization (WHO, 2003) has not derived any health-based guidelines for ammonia (including ammonium) in drinking water as the concentrations are typically below those posing a health concern. The Ministry of Health Care of Vietnam has regulated the limit for ammonia in drinking water to $3 \mathrm{mg} / \mathrm{L}$ (QCVN 01:2009/BYT). The European limit is set to $0.5 \mathrm{mg} / \mathrm{L}(\mathrm{EC}, 1998)$ and is an indicator parameter with regard to fecal contamination, for example. The Southern part of Hanoi has experienced increasing concentrations of ammonium in the deep groundwater over the last 25 years since the Phap Van well field was put into full operation in 1990 (Andersson and Norrman, 1998). High concentrations of arsenic have been another serious quality issue in the Red River delta area in general, and in the Southern part of Hanoi in particular, since the problem was uncovered in 1998 (Berg et al., 2001).

At present, more than 1 million $\mathrm{m}^{3}$ of groundwater is pumped every day in the Red River delta, with 750,000 $\mathrm{m}^{3} /$ day supplying the Hanoi area (Winkel et al., 2011). Approximately 11 million people depend on groundwater from the delta area as their main water source (Berg et al., 2001). Public wells are mainly abstracting water from the lower (Pleistocene) aquifer system, whereas private wells predominantly tap groundwater from the upper (Holocene) aquifer system (Trafford et al., 1996). The heavy abstraction of the lower aquifer has resulted in drawdown of low-quality water from the upper aquifer into the lower aquifer (Norrman et al., 2008; Berg et al., 2008; Winkel et al., 2011).

This study focuses on the Nam Du area south of Hanoi city, where a well-field was constructed and brought into operation in 2004 (Fig. 1) with a groundwater extraction from the Pleistocene aquifer of $60,000 \mathrm{~m}^{3} /$ day. The well-field is situated on the banks of the Red River to take advantage of induced infiltration. The heavy groundwater extraction has however severely affected the area by lowering of the groundwater table. Furthermore, the groundwater in this area is characterized by high concentrations of ammonium and arsenic and the sediments contain large amounts of organic matter, i.e., peat (e.g., Berg et al., 2008). The Hanoi sewage system also drains untreated wastewater to this area, with an outlet to the Red River just south of the Nam Du well field, subsequent to a number of settling ponds with varying connection to other surface bodies (Fig. 1). The reason for the high and increasing concentration of ammonium in the area is not clear. Andersson and Norrman (1998) postulated that two potential sources are mainly responsible for ammonium in the Hanoi region: (1) mineralization of organic nitrogen from peat layers buried in the delta formation, and (2) anthropogenic activities (i.e., wastewater, septic waste, mineral fertilizers, and manure) which cause infiltration of nitrogen-rich water into the groundwater. 


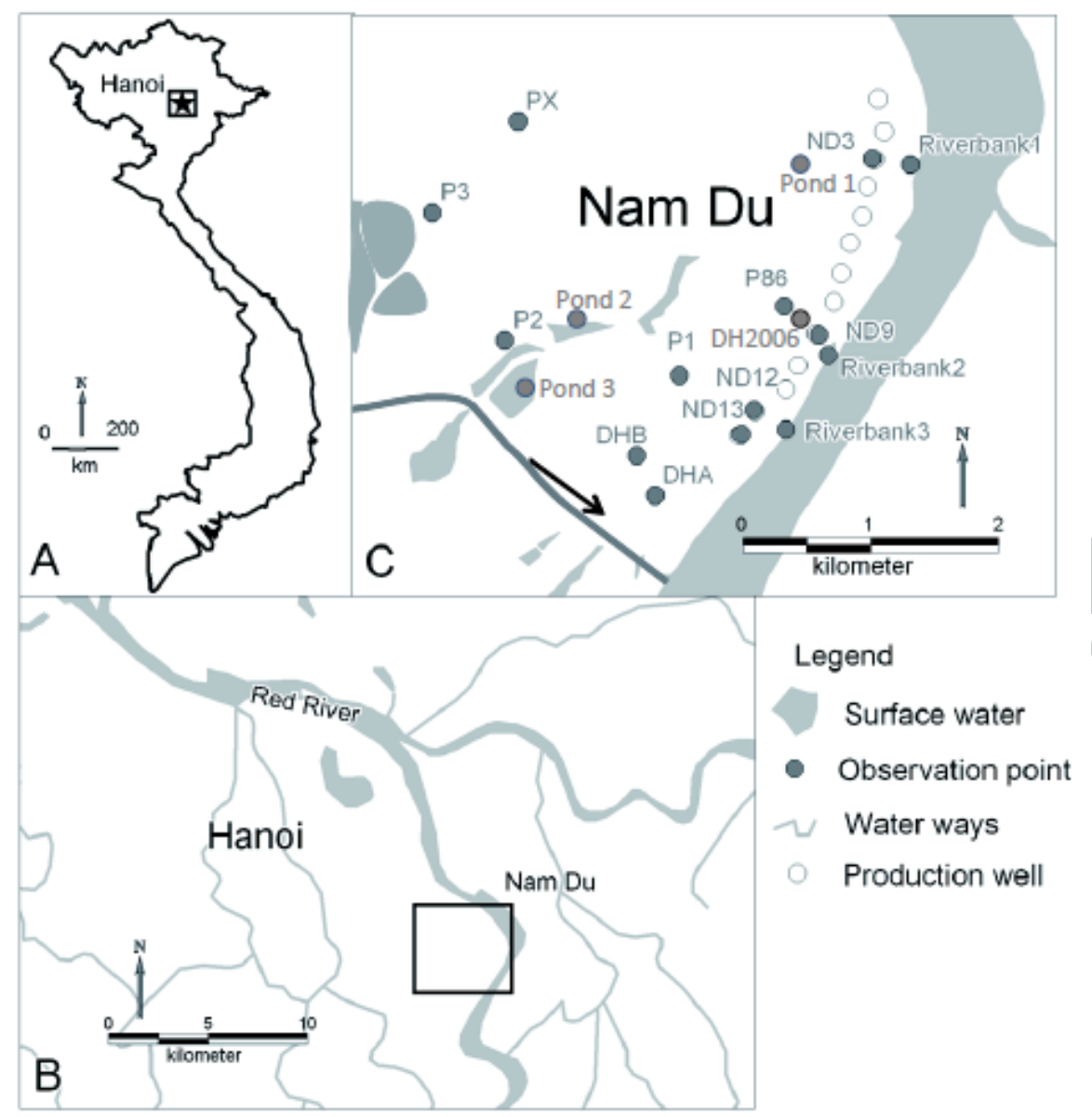

Figure 1. Location of the Nam Du well field South of Hanoi, Vietnam, and the sampling locations used in the study. The outlet of the wastewater channel and the sewage settling ponds is indicated by a black arrow in Fig. 1c (adopted from Norrman et al., 2008).

The main objective of this study was to trace the sources of the elevated ammonium concentrations in the Nam Du groundwater. For this purpose, measurements were made of isotope ratios $\left({ }^{15} \mathrm{~N} /{ }^{14} \mathrm{~N}\right)$ of total nitrogen and exchangeable ammonium in the peat layers, and ammonium in the groundwater and surface waters. Other chemical analysis of the water was also performed to support the conclusions. We hypothesized that the mineralization of peat should create a different ${ }^{15} \mathrm{~N} /{ }^{14} \mathrm{~N}$ ratio in the ammonium ions compared to ammonium ions derived from surface based activities, as described, for example, by Heaton (1986), Kendall and Aravena (2000), and Widory et al. (2004).

\section{Study area: Nam Du}

\subsection{Geology}

The Red River delta plain is located near the coast of the Gulf of Bac Bo (Gulf of Tonkin, South China Sea) and the delta evolution has been greatly affected by sea-level changes since the Last Glacial Maximum (LGM, c. 21 ka BP) (e.g., Trafford et al., 1996; Tanabe et al., 2006). The Quaternary sediment thickness varies in the Hanoi area between 50 and $90 \mathrm{~m}$ (Jussuret et al., 2010). In addition, the geological structure within the present delta plain is 
complex as the area has varied between being a sediment accumulation area beneath sea level and an area of weathering and erosion above sea level.

The lower aquifer system consists of sediments deposited during the Pleistocene (Pleistocene aquifer) and are interpreted as shallow marine deposits of mainly laminated sand and bioturbated clay (Tanabe et al., 2006). The sediments constituting the lower aquifer have a stiff lithology with tanned colors as well as lateritic weathering, indicative of postdepositional oxidizing conditions (Tanabe et al., 2006). The sediment exposure to oxidizing conditions can be explained by the LGM sea-level lowstand and/or crustal uplift as a response to high sediment loading in the Gulf of Tonkin (Hanebuth et al., 2006).

Sediments forming the upper aquifer system were deposited during the Holocene (Holocene aquifer) and these are interpreted as deposited in a changing environment, from a tidal flat to tide-influenced channels and then changing into a floodplain. The upper aquifer consist of 25$40 \mathrm{~m}$ of sand with interlayering of clay and silty clay, containing peat and plant remains (Funabiki et al., 2007; Tanabe et al., 2003a, 2003b;Trafford et al., 1996).

Destructive drillings over the full Quaternary sequence along the Red River in the Nam Du area reveals a total depth of approximately $85 \mathrm{~m}$ of which about $40 \mathrm{~m}$ forms a Holocene river channel filled with sand on top of silt-clay (Jusseret et al., 2010).

\subsection{Hydrology and groundwater flow}

The characteristic delta formation is heterogenic by nature. The contacts between the water bearing formations vary spatially and confining layers are occasionally missing (Trafford et al., 1996). The upper aquifer (within the Holocene sediments) is mostly unconfined, but occasionally semi-confined, receiving recharge mainly from the Red River and by percolating surface water and rainwater (Van et al., 1996). In the Nam Du area, the top of the lower aquifer (Pleistocene sediments) is found at depths of $40 \mathrm{~m}$. The aquifer is confined to semiconfined, as the confining layer is partly missing in some places, causing leakage and recharge from the overlying aquifer as well as from the Red River (Trafford et al., 1996; Tran, 1990).

The southern Hanoi area is characterized by a large depression cone that has evolved from decades of heavy pumping of the well fields Ha Dinh, Tuong Mai, Phap Van, and more recently, Nam Du. The groundwater level in the Pleistocene aquifer shows a clear drawdown in the investigated area due to this pumping (Berg et al., 2008; van Geen et al., 2013; Winkel et al., 2011).

A natural interaction occurs between the aquifers and the Red River, where leakage happens under pristine conditions during the dry season from the Holocene aquifer into the Red River. During the rainy season, river water normally infiltrates into the aquifers. This flow pattern has partly changed due to the heavy pumping within the southern Hanoi area and the predominant situation today is that water infiltrates into the aquifer from the Red River most of the year. The more southern sectors of the Nam Du area are less impacted by the heavy pumping and experience more outflow of groundwater into the river during at least parts of the year (Baric and Sigvardsson, 2007; Harms-Ringdahl, 2007). The water level in the Red River varies naturally by 7-10 m between the dry and rainy seasons, with lowest levels at the end of the dry season. The groundwater table in both the upper and lower aquifers varies naturally by about $4 \mathrm{~m}$ seasonally. 
A previous study by Norrman et al. (2008) showed that the groundwater pumping in Nam Du caused a local drawdown of the groundwater level primarily in the Pleistocene aquifer and to a lesser degree in the Holocene aquifer. The hydraulic head in the Holocene aquifer indicates that the system of more or less connected ponds and sewage settling ponds within the Nam Du area recharge the Holocene aquifers locally.

\subsection{The wastewater system in Hanoi}

In 2008, an estimated daily production of domestic and industrial wastewater of $760,000 \mathrm{~m}^{3}$ was generated in the central areas of Hanoi, of which only $10 \%$ was treated centrally by sedimentation in ponds (Schramm, 2011). About 90.5\% of the households are equipped with septic tanks, but most of them are in poor conditions (Harada et al., 2008) and are thus likely to regularly overflow into the sewerage system. From households without septic tanks, blackwater goes directly into sewer pipes or nearby canals (Kuroda et al., 2015). All graywater from households and stormwater goes into the sewers and canals, together with industrial wastewater (e.g. Huong et al., 2008; Marcussen et al., 2008; Hung et al., 2015). The overall flow direction in the Hanoi area is from north to south, and the wastewater and the stormwater is collected by the canals and transported south of the city: the two main rivers being To Lich and Kim Nguu. At the Yen So WWTP, a fraction of the wastewater is treated (Schramm, 2011; Kuroda et al., 2015). The effluent and the majority of the untreated urban wastewater are discharged together into the Red River at the Yen My site (the outlet canal is shown with a black arrow in Fig. 1C). The rest of the urban wastewater is discharged into the Nhue River in the west (Kuroda et al., 2015).

\section{$3 \quad$ Material and methods}

Field campaigns were carried out during dry season in February-March 2006 and MarchApril 2007. Water samples were collected for chemical analyses from wells within the Holocene aquifer (15 samples in 12 wells at the Nam Du site and 4 samples in 4 wells at the Dan Phuong site; see Larsen et al. (2008) for details of the Dan Phuong site and comments in the discussion Section 5), from wells within the Pleistocene aquifer (15 samples in 11 wells at the Nam Du site and 1 sample at the Dan Phuong site), from shallow groundwater at the river bank in Nam Du (6 samples from 6 different locations), and from surface waters in Nam Du (4 samples from the Red River and 3 from different ponds). Two samples of sewage water were collected in the open sewage channel system, one sample in one of the sewage settling ponds (A) and one sample after (B) the sewage settling ponds.

Ten observation wells were installed by rotational drilling in 2007 at two different locations and at five different depths. Sediment samples were taken for analysis from different depths at two drilling sites. Drilling was also carried out close to the production well ND9 in 2006 to find peat material for analysis. No peat was found during the drilling, but sediment samples were collected at two different depths. Old samples containing peat material from drillings carried out in 2003 for the production well ND16 were analyzed; these were samples that had been stored in open air from 2003-2006. Sediments were also collected from a pond and from the riverbank in 2006. For more detailed information on the sampling campaigns and procedures, see Baric and Sigvardsson (2007), Harms-Ringdahl (2007), Moreskog (2007), and Norrman et al. (2008). The sampling locations are indicated in Figure 1. 


\subsection{Water sampling, field measurements, and chemical analyses}

Sampling procedures are described in detail in Norrman et al. (2008) and will only briefly be presented here. Temperature, $\mathrm{pH}$, electrical conductivity, dissolved oxygen, and redox potential (Eh) of the groundwater were measured in the field via a flow cell. For surface water samples, measurements and sample collection were performed directly in the water.

The water chemistry analyses were carried out at the Swiss Federal Institute of Aquatic Science and Technology (Eawag) using the procedures described in Berg et al. 2008 and Norrman et al. 2008. Samples used for the analysis of metals, $\mathrm{NH}_{4}^{+} ; \mathrm{PO}_{4}{ }^{3-}, \mathrm{As}(\mathrm{III}), \mathrm{As}(\mathrm{V})$, and trace elements were acidified with suprapur $1: 1 \mathrm{HCl}$ to a $\mathrm{pH}<2$, to avoid precipitation. Samples taken for analyses of other major anions, alkalinity and DOC were not acidified. The Institute of Nuclear Science and Technology (INST) carried out the bacteriological analyses, as well as isotopic measurements $\left(\delta^{15} \mathrm{~N}\right.$ and $\left.\delta^{18} \mathrm{O}\right)$ from dissolved nitrate and dissolved ammonium. The samples for nitrogen isotopic analyses were also acidified with suprapur 1:1 $\mathrm{HCl}$ to a $\mathrm{pH}<2$, to avoid precipitation.

Samples for trace element analyses and As speciation were stored at room temperature before and during transport, and at $4^{\circ} \mathrm{C}$ in the dark in the laboratory. All other samples were continuously stored at $4-8^{\circ} \mathrm{C}$ in the dark, except during transport. The chemical constituents in the groundwater samples were quantified in triplicate. The median deviation of the sum of cationic and anionic charge (eq/L) was 3.9\% (range -4-20\%) with an overall coefficient of correlation $\left(\mathrm{r}^{2}\right)$ of 0.98 . The quality assurance measures are given in Berg et al. (2008). Methodology for the different analyses are summarised in Table S1 (Supporting Material).

\subsection{Sediment sampling and analysis}

Sediment samples were collected at different depths during the course of the drilling of the two deepest wells at the DHA and DHB locations in 2007. Depending on the grain size, different core sample devices were used. Ten sediment samples were collected from each of the two locations. The samples were analyzed by sequential leaching, water content, loss on ignition (LOI), Mössbauer, and color at the Earth Science Department at Gothenburg University in Sweden (for further description and results, see Norrman et al., 2008; Sigvardsson and Baric, 2007). The sediment samples were also analyzed for the amount of exchangeable ammonium and for the $\delta^{15} \mathrm{~N}$ value of the exchangeable ammonium, TOC (all at INST), and the N-mineralization potential (at the Centre for Environmental Technology and Sustainable development, CETASD) and loss on ignition (LOI) for total carbon content (Gothenburg University). In 2006, cores were drilled to collect peat samples and although no peat was encountered during the drilling, sediments were collected (for details, see HarmsRingdahl, 2007). In addition, sediment samples with organic material were collected from the core of one of the production wells, ND16, in 2003. The samples from the ND16 core were stored in ambient air until analysis (2006 and 2007). Samples of sediments collected in 2006 were analyzed for exchangeable ammonium (at the Royal Institute of Technology, KTH), and the $\delta^{15} \mathrm{~N}$ and $\delta^{13} \mathrm{C}$ of the Total $\mathrm{N}$ and Total C, respectively (at the Swedish Agricultural University in Umeå, SLU). For a summary, see Table S1 in Supporting Material. 


\section{$4 \quad$ Results}

\subsection{Water}

Table S2 (Supporting Material) shows a summary of concentrations of selected species in the groundwater collected in the dry season in 2006 and 2007. For data on $\mathrm{Fe}, \mathrm{HCO}^{3-}, \mathrm{Mn}, \mathrm{Mo}$, $\mathrm{Sb}$, see Norrman et al. (2008).

The groundwater in the Pleistocene aquifers is typically of bicarbonate type, with low sulfate content below the level of detection (although the sulfate detection limit is high, $5 \mathrm{mg} / \mathrm{l}$ ), with one exception. All major anions and cations were tested for correlations searching for $\mathrm{r}^{2}>0.5$ in the Holocene and the Pleistocene aquifers. The Holocene aquifer demonstrated no clear correlation between ammonium and other elements. In the Pleistocene aquifer, positive relationships were found between $\mathrm{HCO}_{3}$ and As, $\mathrm{Mo}$ and $\mathrm{HCO}_{3}$, Mo and As, As and Ca, and $\mathrm{HCO}_{3}$ showed a strong positive correlation with $\mathrm{Ca}, \mathrm{Mg}$, and $\mathrm{Sr}$ (for details see Norrman et al., 2008). In the same study, positive correlations were also noted between $\mathrm{NH}_{4}$ and $\mathrm{Cl}$ and DOC in the Pleistocene aquifer: $\mathrm{NH}_{4}-\mathrm{Cl}\left(\mathrm{r}^{2}=0.82, \mathrm{n}=15\right)$, and $\mathrm{NH}_{4}-\mathrm{DOC}\left(\mathrm{r}^{2}=0.69, \mathrm{n}=15\right)$. In addition, positive relationships can also be found between $\mathrm{NH}_{4}$ and $\mathrm{Na}\left(\mathrm{r}^{2}=0.73, \mathrm{n}=15\right)$, $\mathrm{NH}_{4}$ and $\mathrm{Ba}\left(\mathrm{r}^{2}=0.65, \mathrm{n}=15\right)$, and $\mathrm{NH}_{4}$ and $\mathrm{Ni}\left(\mathrm{r}^{2}=0.67, \mathrm{n}=15\right)$ in the Pleistocene aquifer, see Figure 2. Using the non-parametric Mann-Kendall test, it was concluded that there are statistically significant evidence of increasing trend at the specified level of significance (0.01) for all afore mentioned positive relationships with $\mathrm{NH}_{4}$. No positive correlation was found between $\mathrm{NH}_{4}$ and $\mathrm{As}, \mathrm{K}$, or $\mathrm{PO}_{4}$.

In general, the ammonium concentrations in the analyzed samples were higher than would be expected in groundwater not affected by anthropogenic activities. The ammonium concentrations in the Holocene and the Pleistocene aquifers show a mean and standard deviation in the Holocene of 18.0 and $13 \mathrm{mg} / \mathrm{l}$, respectively, and 12.2 and $6.9 \mathrm{mg} / \mathrm{l}$ in the Pleistocene. However, a two-sided Welch-Satterthwaite hypothesis test (data approximately normally distributed with unequal variances) for the two samples could not conclude different populations at a confidence level of $95 \%$.
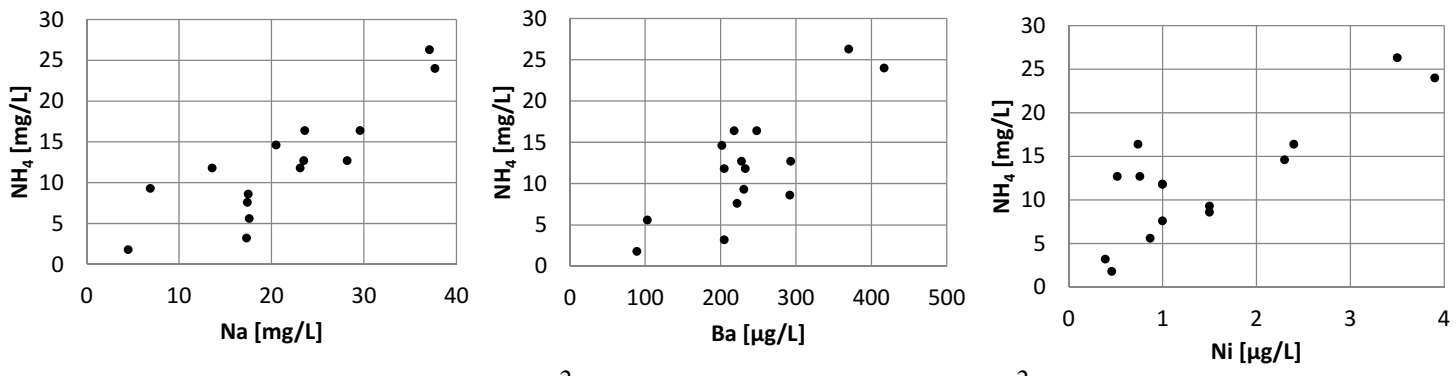

Figure 2. Scatterplots of $\mathrm{NH}_{4}-\mathrm{Na}\left(r^{2}=0.73, n=15\right), \mathrm{NH}_{4}-\mathrm{Ba}\left(r^{2}=0.65, n=15\right)$, and $\mathrm{NH}_{4}$ $\mathrm{Ni}\left(r^{2}=0.67, n=15\right)$. All samples are from the Pleistocene aquifer.

The $\delta^{15} \mathrm{~N}$ values of $\mathrm{N}-\mathrm{NH}_{4}$ for different waters are shown in Fig. 3 together with two theoretical binary mixing lines. An apparent positive relationship exists between the concentration of $\mathrm{NH}_{4}$ and the enrichment in ${ }^{15} \mathrm{~N}$ in ammonium. The groundwater samples from the Holocene and the Pleistocene aquifers in Nam Du showed $\delta^{15} \mathrm{~N}$ values between $10 \%$ o and $22 \%$, with a slightly larger range of values in the Holocene aquifer. For mixing line I, the Red River surface water is used as one end-member and the Holocene groundwater from well 
$\mathrm{P} 1 \mathrm{~B}$, with the highest measured ammonium concentration, represents the other end-member. For mixing line II, the average calculated from the sampled sewage settling ponds are used as the one end-member together with $\mathrm{P} 1 \mathrm{~B}$. A mixing process which is a dilution between a two end-members can be described with a simple binary mixing model. The concentration of substance $\mathrm{X}$ in a binary mixed sample can be described as follows:

$$
[X]=\left[X_{k}\right] \cdot f+\left[X_{p}\right](1-f),
$$

where $\mathrm{Xp}$ is one end-member, $\mathrm{Xb}$ is the baseline end-member and $\mathrm{f}(0 \leq \mathrm{f} \leq 1)$ is the proportion of the baseline end-member in the mixing (Buschmann and Berg, 2009; Widory et al., 2005). When stable isotopes are used as environmental tracers, the following equation system can be obtained (Widory et al., 2005):

$$
[X] \cdot \delta X=\left[X_{\varepsilon}\right] \cdot f \cdot \delta X_{\Sigma}+\left[X_{\%}\right] \cdot(1-f) \cdot \delta X_{\mathrm{q}} .
$$

The equations allows for estimations of mixing if concentrations and isotope ratios are known. In this study, the above mixing models cannot fully explain the concentrations and isotope ratios of the samples. Instead a more complex system than a binary mixing is indicated, with a possible third end-member with lower $\delta^{15} \mathrm{~N}$ ratio and higher $\mathrm{NH}_{4}$ concentration. Figs. $4 \mathrm{a}$ and $\mathrm{b}$ show the $\mathrm{NH}_{4}$ and the $\delta{ }^{15} \mathrm{~N}$ value of different waters as a function of depth. A slight negative trend is evident in the Pleistocene aquifer with depth, which was not observed in the Holocene aquifer.

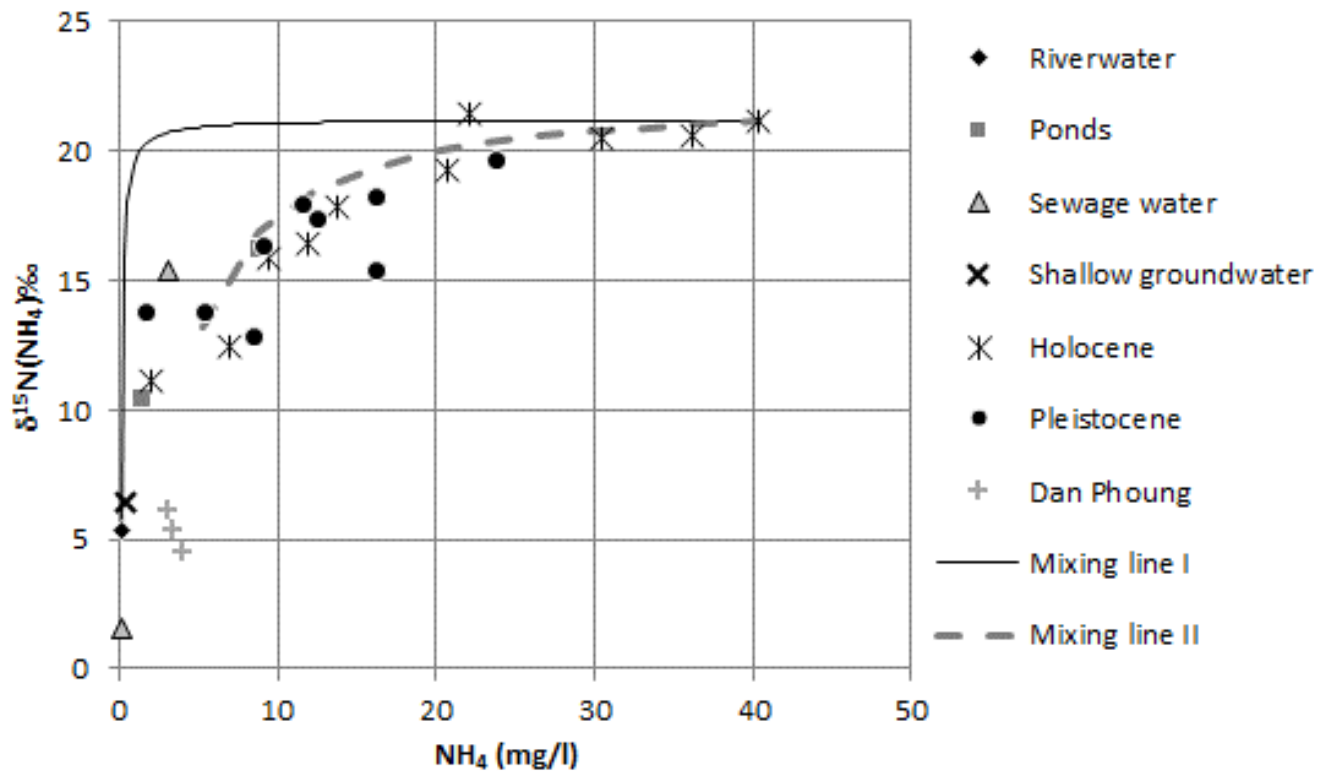

Figure 3. $\delta^{15} \mathrm{~N}$ values of $\mathrm{NH}_{4}{ }^{+}$in water including a theoretical binary mixing model (mixing line), where the Red River surface water is used as the baseline end-member for mixing line I and the average measured values from sewage settling ponds for mixing line II, and the Holocene groundwater in well PIB (where ammonium concentration is the highest measured), as the other end-member for both. 

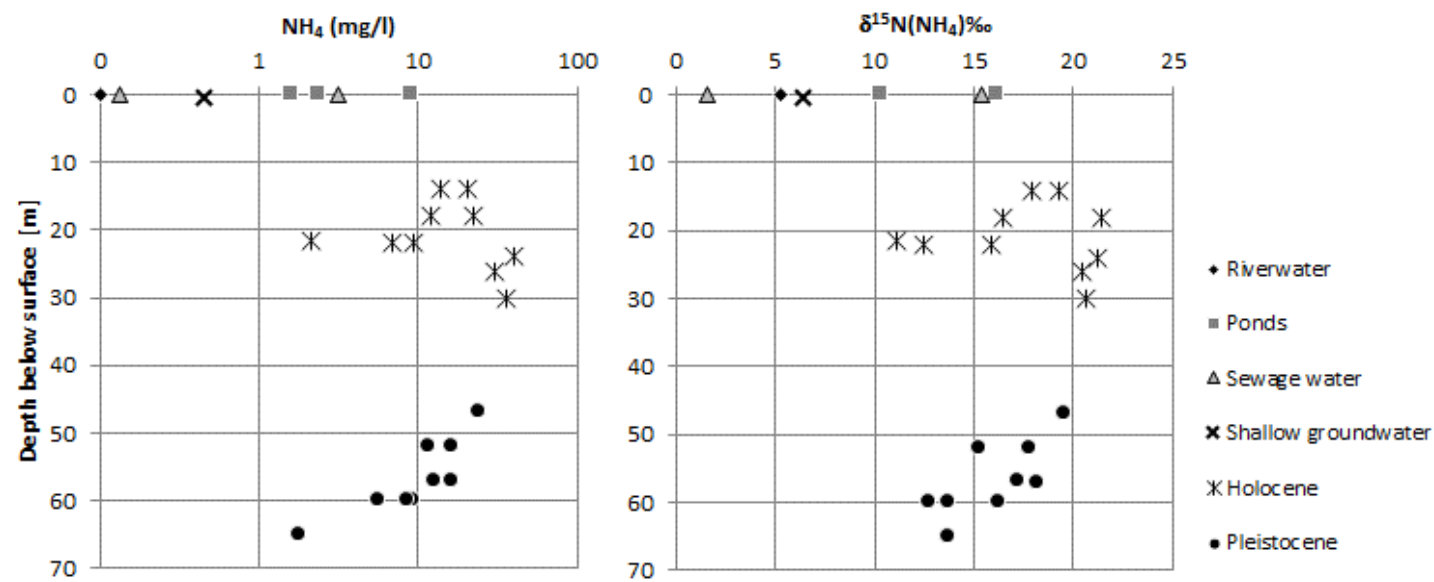

Figure 4. a) $\mathrm{NH}_{4}^{+}$concentration in water by depth (logarithmic scale on the x-axis). b) $\delta^{15} \mathrm{~N}$ values of $\mathrm{N}-\mathrm{NH}_{4}$ in water by depth.

The $\delta^{18} \mathrm{O}$ and $\delta^{15} \mathrm{~N}$ values in $\mathrm{N}-\mathrm{NO}_{3}$ are shown in Fig. 5. Only one sample from the aquifers contained any nitrate, due to the strongly reducing conditions in the groundwater. The bacteriological content in the groundwater is shown in Table 1. The correlation with ammonium was investigated by Baric and Sigvardsson (2007), but could not be confirmed. Escherichia coli (E. coli) was found in DHB at $14 \mathrm{~m}$ depth, where the highest counts of total coliform bacteria were also found, which clearly indicated influence from the surface.

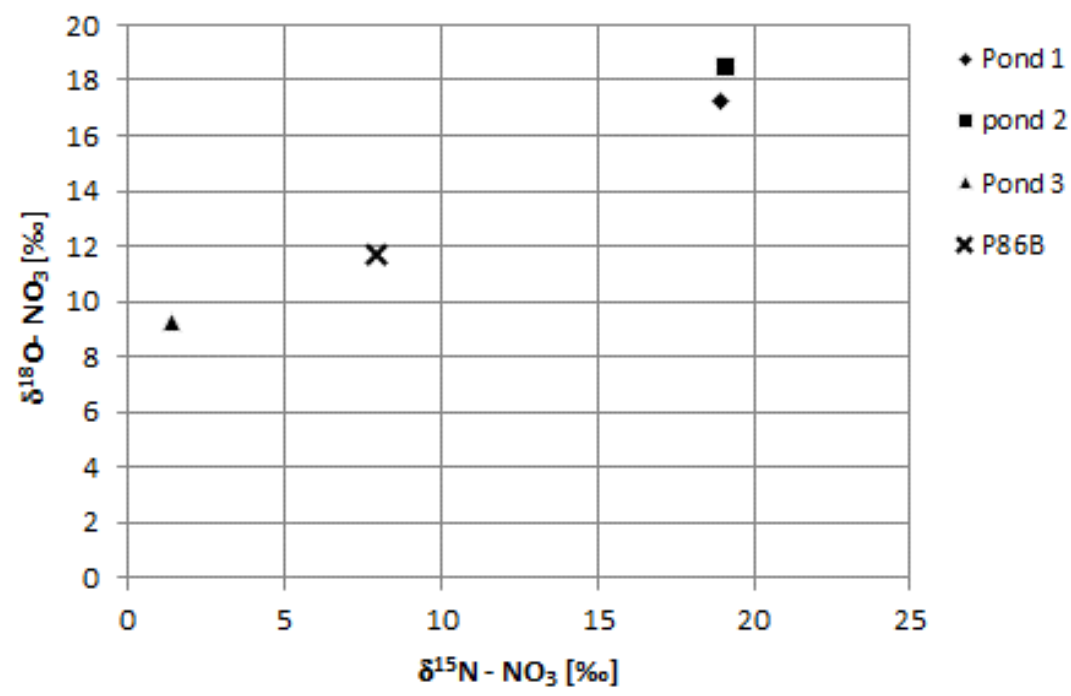

Figure 5. $\delta^{18} \mathrm{O}$ and $\delta^{15} \mathrm{~N}$ values of $\mathrm{NO}_{3}$ in water. 
Table 1. Bacteriological content in the groundwater

\begin{tabular}{|l|c|c|}
\hline Sample location & $\begin{array}{c}\text { Total coliform bacteria } \\
{[\text { o./100 ml] }}\end{array}$ & $\begin{array}{c}\text { E. coli } \\
{[\text { no./100 ml] }}\end{array}$ \\
\hline DHB 14 & 110000 & 9300 \\
\hline DHB 18 & 20 & n.d. $^{\text {a) }}$ \\
\hline DHB 22 & 93 & n.d. $^{\text {a) }}$ \\
\hline DHB 26 & 23 & n.d. $^{\text {a) }}$ \\
\hline DHB 52 & 48 & n.d. $^{\text {a) }}$ \\
\hline P3A & 28 & n.d. $^{\text {a) }}$ \\
\hline P3B & 28 & n.d. $^{\text {a) }}$ \\
\hline ND9 & 48 & n.d. $^{\text {a) }}$ \\
\hline ND13 & 75 & n.d. $^{\text {a) }}$ \\
\hline
\end{tabular}

a) Under the detection limit of 3/100 ml.

\subsection{Sediments}

The aquitard dividing the Holocene and Pleistocene aquifers in DHA and DHB reaches from 30-48 m depth. Sediment samples were collected from the Holocene layers; the deepest sample is from just above the top of the Pleistocene ( $46 \mathrm{~m})$. In Figs. 6 and 7, LOI, exchangeable $\mathrm{NH}_{4}$, and the $\delta^{15} \mathrm{~N}$ ratios of the exchangeable $\mathrm{NH}_{4}$ are plotted by depth together with the ammonium concentration and associated $\delta^{15} \mathrm{~N}$ ratios in groundwater, in DHA and DHB, respectively.

Ammonium concentrations in the sediments were highest around 30-40 m below surface. At

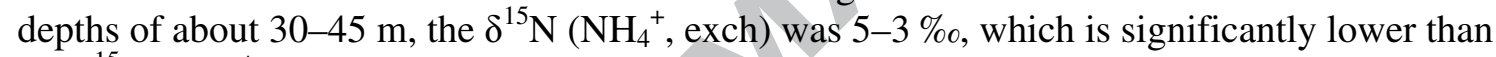
the $\delta^{15} \mathrm{~N}\left(\mathrm{NH}_{4}{ }^{+}(\mathrm{aq})\right.$ ) measured in the groundwater at depths above $30 \mathrm{~m}$ and below $45 \mathrm{~m}$ (see Fig. $4 \mathrm{~b}$ for a comparison). However, no data are available for the $\delta^{15} \mathrm{~N}$ in the pore-water at depths 30-45 m below the surface, as no wells were installed due to the low flow in the finegrained material. 


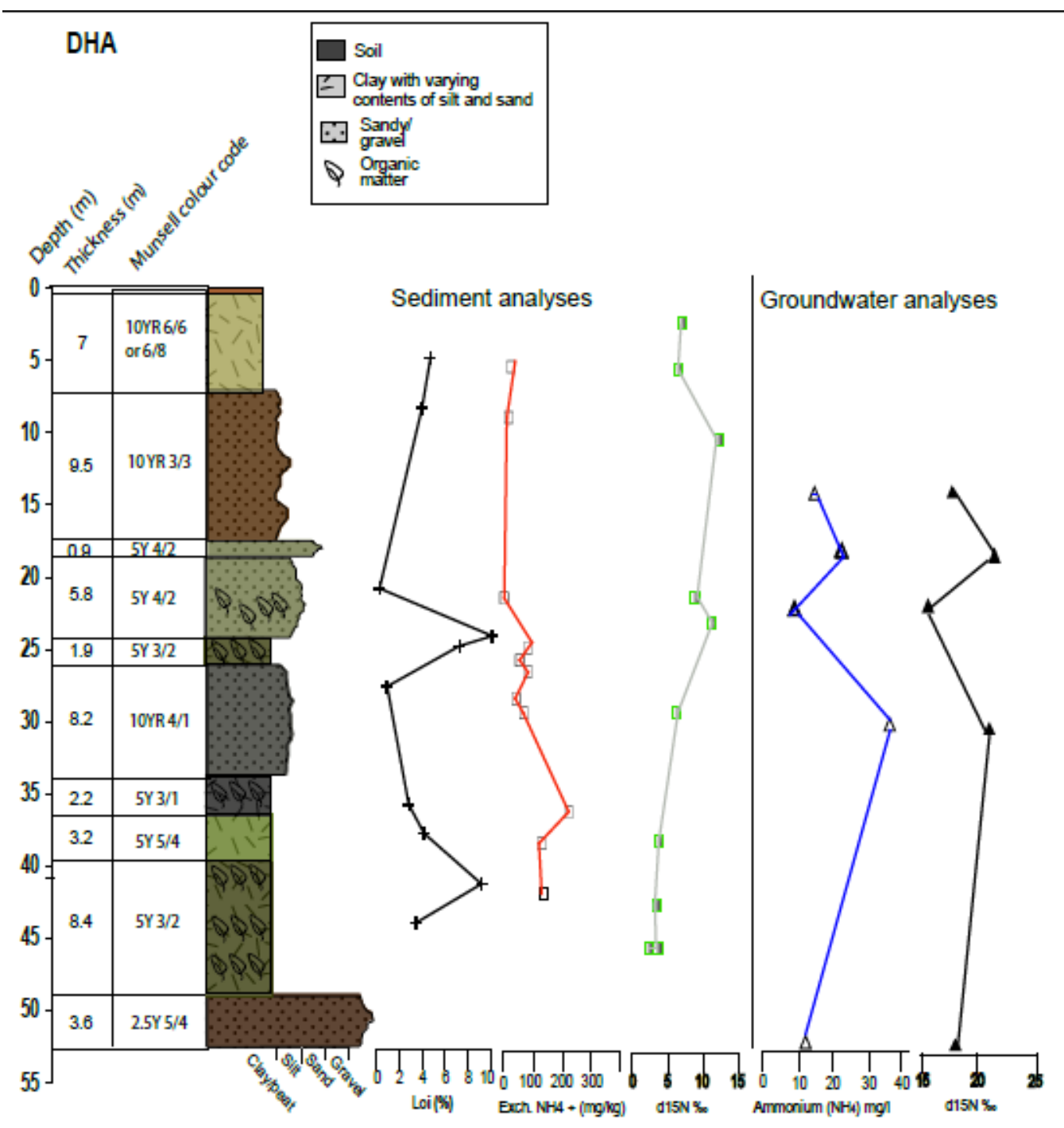

Figure 6. Loss on ignition (LOI), exchangeable $\mathrm{NH}_{4}, \delta^{15} \mathrm{~N}$ values of the exchangeable $\mathrm{N}-\mathrm{NH}_{4}$ and ammonium concentration and associated $\delta^{15} \mathrm{~N}$ ratios in groundwater in DHA. 


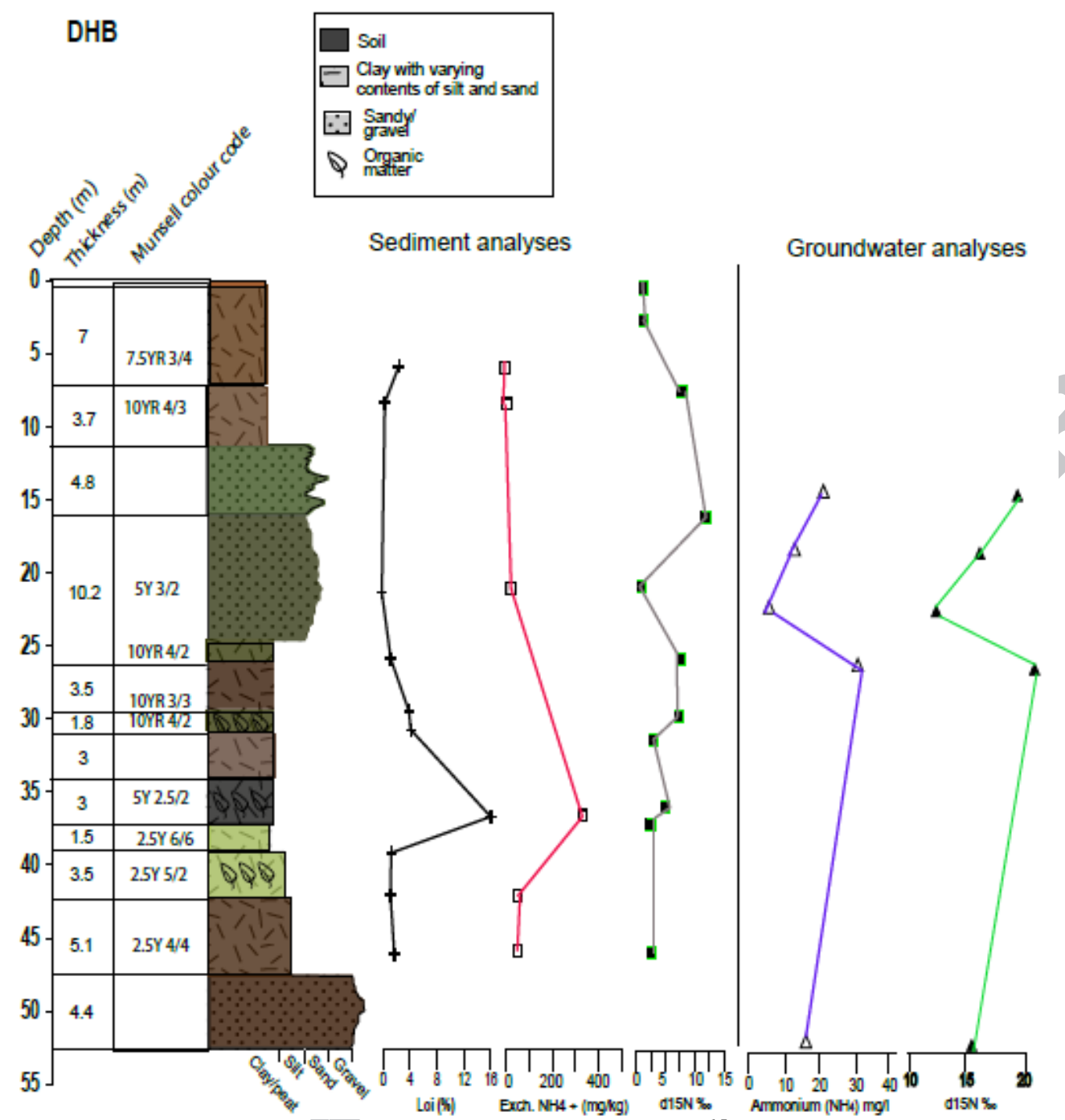

Figure 7. Loss on ignition (LOI), exchangeable $\mathrm{NH}_{4}, \delta^{15} \mathrm{~N}$ values of the exchangeable $\mathrm{N}-\mathrm{NH}_{4}$ and ammonium concentration and associated $\delta^{15} \mathrm{~N}$ ratios in groundwater in DHB.

In 2006, Harms-Ringdahl (2007) analyzed old sediment samples containing organic matter (peat), collected from the drilling of production well ND16 in 2003, for $\delta^{15} \mathrm{~N}$ and $\delta^{13} \mathrm{C}$ of total $\mathrm{N}$ and $\mathrm{C}$; see Table 2. Table 3 shows the results from the analyses of the nitrogen mineralization potential in the sediment samples. It should be noted that the composition of the sediments can vary spatially, even within short distances of few meters.

Table 2. Isotopic signatures and concentrations of sediment-bound $C$ and $N$.

\begin{tabular}{|c|c|c|c|c|c|c|}
\hline & Depth [m] & $\begin{array}{c}\mathbf{C}[\text { [mass } \\
\text { fraction] }\end{array}$ & $\begin{array}{c}\mathbf{N} \text { [mass } \\
\text { fraction] }\end{array}$ & $\boldsymbol{\delta}^{13} \mathbf{C}$ & $\delta^{15} \mathbf{N}$ & $\mathbf{C} / \mathbf{N}$ \\
\hline ND16 & 23 & 4.5 & 0.1 & -27.7 & 2.4 & 34.4 \\
\hline ND16 & 44 & 18.7 & 0.5 & -27.5 & 4.1 & 40.3 \\
\hline
\end{tabular}


Table 3. Nitrogen mineralization potential in the sediments.

\begin{tabular}{|c|c|c|c|}
\hline \multirow{2}{*}{ Sample } & \multicolumn{2}{|c|}{ Anaerobic incubation, 7 days } & Difference \\
\cline { 2 - 4 } & $\mathbf{N}$ control & $\begin{array}{c}\mathbf{N} \text { after } \\
\text { incubation }\end{array}$ & Mineralized N \\
\hline DHA35.5 (1) & 300.5 & 298.0 & $(-2.5)$ \\
\hline DHA35.5 (2) & 303.0 & 287.5 & $(-15.5)$ \\
\hline DHA44.4 (1) & 64.5 & 68.0 & 3.5 \\
\hline DHA44.4 (2) & 64.0 & 68.5 & 4.5 \\
\hline DHB41.8 (1) & 72.5 & 73.5 & 1.0 \\
\hline DHB41.8 (2) & 73.0 & 73.0 & 0.0 \\
\hline DHB35.5 (1) & 287.0 & 293.5 & 6.5 \\
\hline DHB35.5 (2) & 288.5 & 310.0 & 21.5 \\
\hline
\end{tabular}

\section{Discussion}

At least two main pools can be considered as sources of the dissolved ammonium in the groundwater at Nam Du: infiltrating nitrogen-rich water from the surface and organic nitrogen from the buried peat and abundant organic matter. Figure 8 shows a summary of $\delta^{15} \mathrm{~N}$ values derived both from literature and measured in Nam Du as well as in Dan Phuong. The highest $\delta^{15} \mathrm{~N}$ values are found in the groundwater in Nam Du. In fact, the $\delta^{15} \mathrm{~N}$ values in the groundwater are clearly higher than the $\delta^{15} \mathrm{~N}$ values of total $\mathrm{N}$ in the sediments, and to some degree also higher than in exchangeable $\mathrm{NH}_{4}{ }^{+}$in the sediments, as well as the $\delta^{15} \mathrm{~N}$ values of $\mathrm{NH}_{4}{ }^{+}$in sewage and surface water. This indicates an enrichment of ${ }^{15} \mathrm{~N}$ in the dissolved ammonium in the aquifers. The only known process which would enrich ${ }^{15} \mathrm{~N}$ in $\mathrm{N}_{-} \mathrm{NH}_{4}$ under anaerobic conditions is dissociation of ammonium to ammonia. According to Kendall and Aravena (2000), the $\delta^{15} \mathrm{~N}$ in the residual ammonium ions may be well above $20 \%$ o. Li et al. (2012) found that isotopic fractionation primarily takes place during the conversion of $\mathrm{NH}_{4}{ }^{+}$(aq) to $\mathrm{NH}_{3}(\mathrm{aq})$. Further, Li et al. (2012) concluded that ammonium can deprotonate to ammonia in conditions above $\mathrm{pH} 6$, and the ammonia product can degas, particularly in the range of water temperatures of $19-27^{\circ} \mathrm{C}$ as is the case in Nam Du. The $\mathrm{pH}$ ranges from 6.29 to 7.35 in the Holocene aquifer and from 6.29 to 8.28 in the Pleistocene aquifer (most values below $\mathrm{pH} 7$ ). The strongly reducing conditions in the aquifers also produces methane (Postma et al., 2007) and Gerber et al. (2013) found that depleted stable noble gas concentrations correlated with high concentrations of dissolved methane, suggesting that degassing occurred due to the high methane partial pressure in the Pleistocene aquifer in the south of Nam Dinh Province, Red River Delta, Vietnam. Under such conditions, ammonia will likely be degassed, thereby shifting the reaction $\left(\mathrm{NH}_{4}{ }^{+}(\mathrm{aq}) \leftrightarrow \mathrm{NH}_{3}(\mathrm{aq}) \rightarrow \mathrm{NH}_{3}(\mathrm{~g})\right)$ to the right. The remaining ammonium ions will thus be enriched in ${ }^{15} \mathrm{~N}$. The groundwater would in turn theoretically be depleted in ammonium, but this relationship is not shown in data, instead there is a positive relationship between $\delta^{15} \mathrm{~N}$ in ammonium and the ammonium concentration in groundwater (Fig. 3). This is possibly explained by an increase in $\delta^{15} \mathrm{~N}$ associated with a constant release of ammonium from organic material that balances the loss of ammonia.

The measured $\delta^{15} \mathrm{~N}$ values of the dissolved ammonium ions in groundwater are significantly lower in Dan Phuong (4-6\%o) compared to Nam Du. At Dan Phuong, all samples contained 
traces of nitrate, indicating a more oxic environment. The Dan Phuong area is located $30 \mathrm{~km}$ NW of Hanoi upstream along the Red River (for details see Larsen et al., 2008). It is an abandoned sandbar island outside of the dyke, situated in a river bend intersected by two minor distributaries to the Red River. The total thickness of the Holocene and the Pleistocene layers here are about 50-60 m. The Holocene layers have sand containing disseminated fragments of organic material and clay-rich layers with larger plant fragments and roots, but no peat layers. There is no large abstraction in the area and the groundwater level and recharge is dominated by the seasonal fluctuation of precipitation and the water level of the Red River. Postma et al. (2007) described the groundwater chemistry of the Dan Phuong site where the degradation of organic matter is an important process in the aquifer and is associated with the classical redox sequence (oxygen, nitrate, manganese, iron, sulphate and methane). Arsenic is associated with the redox conditions, with As(total) concentrations in the Holocene aquifer reaching up to $7 \mu \mathrm{M}(525 \mu \mathrm{g} / \mathrm{l})$. The $\mathrm{NH}_{4}$ concentrations reach up to 0.4 $\mathrm{mM}(7.2 \mathrm{mg} / \mathrm{l})$ in the most reduced part of the Holocene aquifer where also production of methane gas is shown. Postma et al. (2007) concludes that the $\mathrm{NH}_{4}$ concentration is a good indicator of the intensity of organic matter degradation due to the good correlation of methane and $\mathrm{NH}_{4}$ in Dan Phuong. The load of nutrients from the surface is considerably less than in Nam $\mathrm{Du}$, but some nutrient load originating from the small village and the agricultural activities on the sandbar island is likely. The difference in $\delta^{15} \mathrm{~N}$ values between Nam Du and Dan Phuong are likely due to that the process of dissociation of ammonium to ammonia is not present at the same rate in Dan Phuong, as a result of lower concentrations of ammonium. The lower ammonium concentrations are likely due to that (1) the natural source of nitrogen is smaller compared to the Southern parts of Hanoi, (2) a lower nutrient load from the surface, and (3) no induced downward flow from the Holocene to the Pleistocene aquifer.

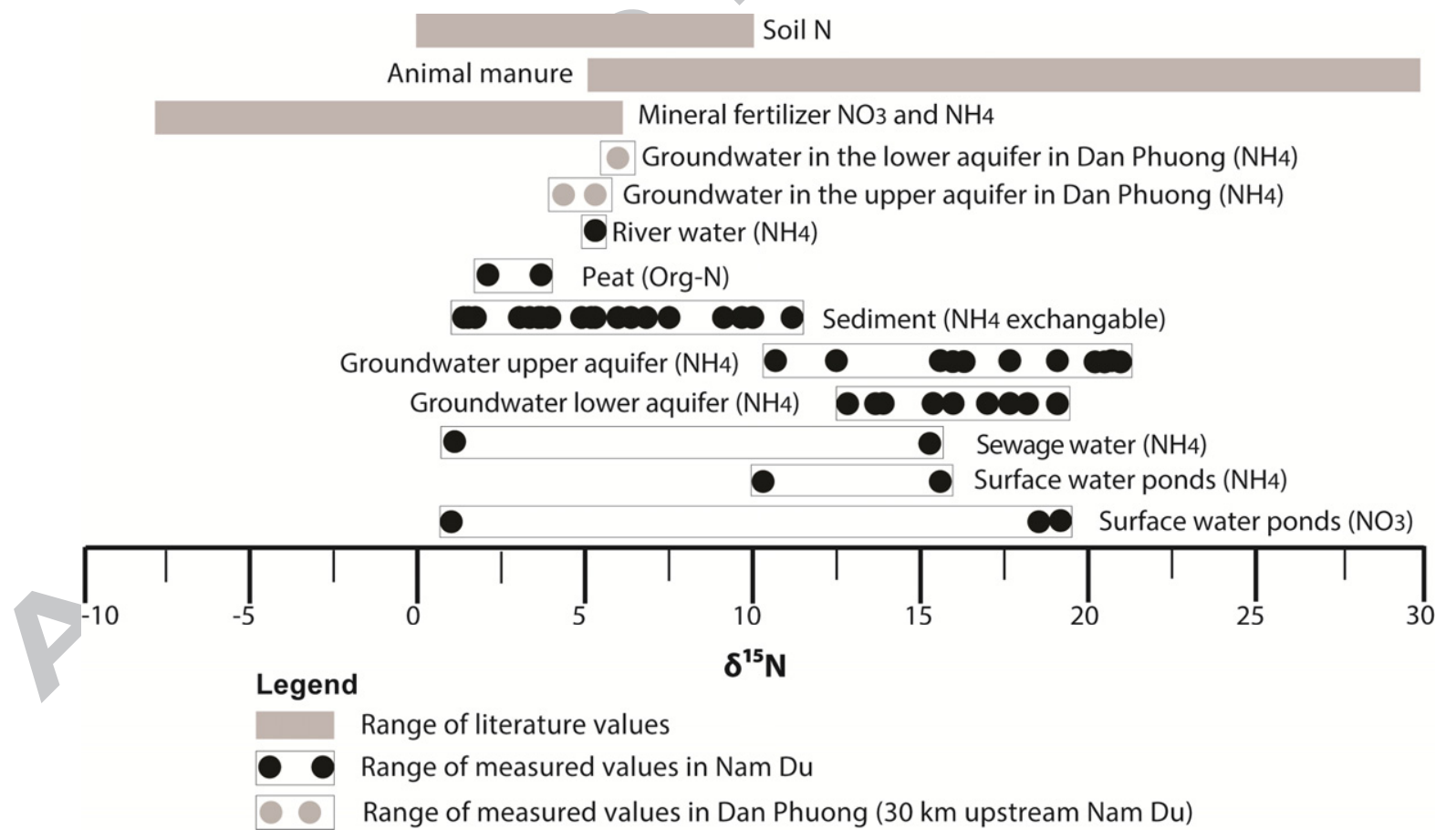

Figure 8. Comparison of $\delta^{15} N$ values in Nam Du (this study) and in Dan Phuong (this study) with ranges of literature (Heaton, 1986; Kendall and Aravena, 2000; Widory et al., 2004). 
Several studies in similar aquifer conditions as in Nam Du concluded that elevated levels of ammonium are derived from organic layers in the soil (e.g. Jiao et al., 2010; Wang et al., 2013; Berg et al., 2008, Postma et al., 2007). The measured $\delta^{15} \mathrm{~N}$ value of total $\mathrm{N}$ in the peat in Nam Du is 2-4\%o. Mineralization of Organic-N does not imply any noticeable fractionation according to Kendall and Aravena (2000) and Hoefs (1997). Hinkle et al. (2007) conclude that ammonium concentrations up to $38 \mathrm{mg} / \mathrm{l}$ in groundwater were due to a natural source; i.e., mineralization of organic $\mathrm{N}$, with measured $\delta^{15} \mathrm{~N}$ values of ammonium of 2.5$3.9 \%$ o. For $\mathrm{NH}_{4}$ concentrations reaching up to $700 \mathrm{mg} / \mathrm{l}$ in aquitard pore water of the Pearl River delta (China), Wang et al. (2013) reported $\delta^{15} \mathrm{~N}$ between $4.7-7.4 \%$, concluding that the ammonium originates from naturally abundant organic matter. The $\mathrm{N}$-mineralization potential of the sedimentary organic matter determined in our study at two different depths in DHA and DHB was low (0-6.5 $\mu \mathrm{g} \mathrm{NH} / \mathrm{g}$, Table 3) compared to measured values of up to $528 \mu \mathrm{g} \mathrm{NH} / \mathrm{g}$ in peat by Hart et al. (1986). However, Stenberg et al. (1998) reported even lower values ranging from $0.005-0.04 \mu \mathrm{g} \mathrm{NH}_{4} / \mathrm{g}$ for 6 days incubation, on different soils with much lower $\mathrm{C} / \mathrm{N}$ ratios than the peat at Nam Du. The relatively high $\mathrm{C} / \mathrm{N}$ ratio in the two peat samples from Nam Du indicates an N-poor environment. However, the $\mathrm{C} / \mathrm{N}$ ratio was not measured on any layers with pure peat in this study, so additional analyses on fresh peat would be valuable.

The theoretical binary mixing model line I (Holocene 1B and Red River water as endmembers) in Fig. 3 has a poor fit to the measured data in Nam Du, while the binary mixing model line II shows a better fit. The mixing line II (sewage settling ponds and Holocene 1B as end-members) does however indicate an internal source to fully explain the elevated $\mathrm{NH}_{4}{ }^{+}$ concentrations and levels of $\delta^{15} \mathrm{~N}$ in the Holocene aquifer. However, the mixing line I cannot fully explain the measurements in the Pleistocene aquifer: instead a more complex system is present. The hydrological conditions in Nam Du are likely to be transient as the pumping in the new well-field has changed the hydrogeological regime, starting before our sampling campaigns, but at the time of the sampling not yet in equilibrium. The recharge from the Red River has increased, and will likely increase even more with time, and the groundwater table in Pleistocene has been lowered. Figures 6 and 7 shows that the measured $\delta^{15} \mathrm{~N}$ values of exchangeable $\mathrm{NH}_{4}$ in the sediments varies between 0.5 and $12 \%$, with highest values around $10-25 \mathrm{~m}$ depths at the locations DHA and DHB. The exchangeable $\mathrm{NH}_{4}$ in the sediments varies from near zero to more than $300 \mathrm{mg} / \mathrm{kg}$ sediment.

Isotopic signatures for $\mathrm{N}$ and $\mathrm{O}$ in nitrate in the Nam Du samples, where nitrate was present, are plotted in Fig. 5. Comparison of the results to similar plots (e.g. Chang et al., 2002; Mayer et al., 2002; Mengis et al., 2001) shows that the sample from Pond 3 seems to be associated with either nitrate from nitrification in soils or ammonium or nitrate from $\mathrm{NH}_{4} \mathrm{NO}_{3}$ fertilizer. The samples from observation well P86b (Holocene aquifer) and Ponds 1 and 2 have higher values of both $\delta^{15} \mathrm{~N}$ and $\delta^{18} \mathrm{O}$, potentially indicating a denitrification trend. In our study, there are unfortunately relatively few samples of surface water and sewage water. Figure 4a shows that the highest ammonium concentrations in all water samples can be found in the groundwater (up to $40 \mathrm{mg} / \mathrm{l}$ in the lower part of the Holocene aquifer and up to $26 \mathrm{mg} / \mathrm{l}$ in the upper part of the Pleistocene aquifer). Huong et al (2008) report nitrate concentrations ranging from 4.1 to $7.4 \mathrm{mg} / \mathrm{l}$ in wastewater collected before the Yen So pumping station in the Kim Nguu and the To Lich rivers. Dao et al. (2010) reports concentrations of total nitrogen ranging from $8-13 \mathrm{mg} / \mathrm{l}$ in the same two rivers. An influence from the open sewage settling ponds and channels in Nam Du can be supported by the bacteriological content, as coliform bacteria are found both in the Holocene and Pleistocene aquifers (Table 1). In the Pleistocene aquifer, $\mathrm{NH}_{4}$ correlates positively with $\mathrm{DOC}, \mathrm{Cl}, \mathrm{Ni}, \mathrm{Ba}$, and Br. Trafford et al. (1996) describe the 
elevated concentrations of $\mathrm{Cl}^{-}$and $\mathrm{HCO}_{3}$ in the groundwater beneath Hanoi city as a possible sign of the influence of the sewage system. However, no positive relationship between $\mathrm{NH}_{4}$ and $\mathrm{K}$ or $\mathrm{PO}_{4}$ was found.

A positive correlation was apparent between $\mathrm{Na}$ and $\mathrm{NH}_{4}$ (Fig. 2), being ions which compete for exchange sites at negatively charged surface sites on clay minerals and organic matter. An increasing concentration of either ion could cause an increasing concentration of the other ion due to competition (Seitzinger et al., 1991). Jiao et al. (2010) observed a close correlation between ammonium and TDS (total dissolved solids) in the Pearl River Delta, China, where the high salinity is attributed to paleo-seawater. In our study, the exchangeable ammonium ions in the deeper sediments ranged from less than 10 and up to $320 \mathrm{mg} \mathrm{NH} / \mathrm{kg}$ (see Figures 6 and 7), with potentially large amounts of ammonium ions being available from the sediments at spatially varying degrees. The Neogene formation below the Pleistocene aquifer locally (south-western part of Hanoi) contains brackish water (Bui et al., 2012), and an increased extraction of groundwater could cause an upward flow of more saline water from the Neogene formations. Another possible explanation for the observed relationship is that the source of both ammonium and sodium ions is sewage water, which often is enriched in both (Ozaki et al., 2014). The results in this study could however not identify any surface source with neither high enough sodium nor nitrogen levels that can explain the higher levels in the Holocence and Pleistocene aquifers.

\section{Conclusions}

Based on the findings in this study, the following conclusions are drawn:

- The $\delta{ }^{15} \mathrm{~N}$ values in the Holocene aquifer are higher than in any of the hypothesized sources, i.e. the surface and waste water samples and in the Holocene sediments, see Figure 8 . The strongly reducing conditions in the aquifers will maintain nitrogen as ammonium in groundwater and under the current temperature and $\mathrm{pH}$ conditions, ammonium tends to deprotonate to ammonia, which can degas from the groundwater table to the unsaturated pore space. This process appears to dominate within the Holocene aquifer and causes an enrichment of ${ }^{15} \mathrm{~N}$ in the remaining ammonium. The degassing of the aquifer, as indicated by Postma et al. (2007), can explain why the ammonium increases in $\delta^{15} \mathrm{~N}$-values as ${ }^{14} \mathrm{~N}$ ammonia leaves the system by diffusion together with $\mathrm{CH}_{4}$ produced from decomposition of organic material within the reducing aquifer.

- The likely process does not, however, clearly indicate the original source of ammonium. There are several indications of influence from anthropogenic activities: the large drawdown in the Pleistocene aquifer and subsequent downward gradient and thereby leakage from the upper aquifer; the bacteriological content; the positive correlation between ammonium and $\mathrm{DOC}, \mathrm{Cl}, \mathrm{Br}$ and $\mathrm{Ni}$. However, the higher concentrations of ammonium in the groundwater $(1.8-40.3 \mathrm{mg} / \mathrm{l})$ compared to the potential surface sources $(0.1-9 \mathrm{mg} / \mathrm{l})$, the positive correlation between ammonium and DOC, the abundance of natural organic matter as well as amount of exchangeable ammonium in the sediments, and the highly reducing conditions in the aquifers indicates that a substantial amount of the ammonium in the groundwater is derived from mineralization of organic nitrogen in the organic matter in the Holocene aquifer-aquitard system.

Confirmation that the enrichment of ${ }^{15} \mathrm{~N}$ is due to degassing of $\mathrm{NH}_{3}$ will require further studies where gas is trapped from the aquifer sediments and analyzed for ammonia. Influences 
of surface activities may threaten groundwater with contaminants other than ammonium, so confirmation of this influence by analysis of persistent anthropogenic tracer molecules, such as recalcitrant pharmaceuticals and pesticides, would also be valuable. The study of the longterm evolution of groundwater quality under the substantially altered hydraulic regime in the Hanoi area should also continue in order to supply the inhabitants of Hanoi with drinking water of high quality.

\section{Acknowledgements}

This work was financed by the Research Council of the Swedish International Development Agency (Sida/SAREC), the Swedish Research Council (VR 348-2008-6215), and the Swedish Geotechnical Institute (SGI). The field work was carried out by Peter Harms-Ringdahl, Johanna Moreskog, Emma Sundberg (prev. Sigvardsson), and David Baric, but could not have been possible without the help of Vietnamese students and personnel at the Hanoi University of Mining and Geology (HUMG), personnel at the Institute of Nuclear Science and Technology (INST) in Hanoi, and personnel from The Research Centre for Environmental Technology and Sustainable Development (CETASD). Personnel from the Division for Water Resources Planning and Investigation for the North of Viet Nam (prev. Hydrogeological Division No 2) and from Hanoi Water Business Company were very helpful and made our sampling and study possible. Caroline Stengel from Eawag is acknowledged for various water analyses. Many thanks to the Danida project team who let us sample at the Dan Phuong site. Professor Dan Berggren-Kleja at the Swedish Agricultural University and the Swedish Geotechnical Institute provided valuable input to the manuscript. At last, but not least, an anonymous reviewer provided comments which highly improved the manuscript.

\section{References}

Andersson, L., Norrman, J., 1998. Ammonium contamination of groundwater in the Hanoi area, Vietnam. Master's Thesis B454. Department of Geology. Chalmers University of Technology, Sweden.

Baric, D., Sigvardsson, E., 2007. Distribution and mobilisation of arsenic in Red River delta aquifers, Vietnam. Master's Thesis B529. Department of Earth Sciences, Geology, Gothenburg University, Sweden.

Berg, M., Tran, H.C., Nguyen, T.C., Pham, H.V., Schertenleib, R., Giger, W., 2001. Arsenic contamination of groundwater and drinking water in Vietnam: A human health threat. Environ. Sci. Technol. 35 (13), 2621-2626.

Berg, M., Trang, P.T.K., Stengel, C., Buschmann, J., Viet, P.H., Dan, N.V., Giger, W., Stuben, D., 2008. Hydrological and sedimentary controls leading to arsenic contamination of groundwater in the Hanoi area, Vietnam: The impact of iron-arsenic ratios, peat, river bank deposits, and excessive groundwater abstraction. Chem. Geol. 249, 91-112.

Bui, D.D., Kawamura, A., Tong, T.N., Amaguchi, H., Trinh, T.M., 2012. Aquifer system for potential groundwater resources in Hanoi, Vietnam. Hydrol. Process. 26 (6), 932-946.

Chang, C.C.Y., Kendall, C., Silva, S.R., Battaglin, W.A., Campbell, D.H., 2002. Nitrate stable isotopes: Tools for determining nitrate sources among different land uses in the Mississippi River Basin. Can.J. Fish. Aquat. Sci. 59 (12), 1874-1885.

Dao, A. D., Con, P. M., Khai, N. M., 2010. Characteristic of urban wastewater in Hanoi City - nutritive value and potential risk in using for agriculture. VNU J. of Science, Earth Sciences 26, $42-47$.

EC, 1998. COUNCIL DIRECTIVE 98/83/EC on the quality of water intended for human consumption. European Community.

Funabiki, A., Haruyama, S., Quy, N.V., Hai, P.V., Thai, D.H., 2007. Holocene delta plain development in the song hong (Red River) delta, Vietnam. J. Asian Earth Sci. In Press, Accepted Manuscript.

Gerber, C., Purtschert, R., Larsen, F., Hoang, H.V., Tran, L.V., Tran, L.T., Pham, N.Q., Sültenfuss, J., 2013. 39Ar groundwater dating of a coastal aquifer in the Nam Dinh Province, Vietnam. Geophysical Research Abstracts. Vol. 15, EGU2013-10113, EGU General Assembly 2013. 7-12 April, 2013 in Vienna, Austria, id. EGU2013-10113 
Hanebuth, T.J.J., Saito, Y., Tanabe, S., Vu, Q.L., Ngo, Q.T., 2006. Sea levels during late marine isotope stage 3 (or older?) reported from the Red River delta (northern Vietnam) and adjacent regions. Quat. Int. 145-146, 119-134.

Harada, H., Dong, N.T., Matsui, S., 2008. A measure for provisional-and-urgent sanitary improvement in developing countries: Septic-tank performance improvement. Water Sci. Tech. 58 (6), 1305-1311.

Harms-Ringdahl, P., 2007. Identifying possible sources of ammonium ions and arsenic in groundwater in the Nam Du area, Vietnam. Swedish University of Agricultural Sciences, Department of Soil Sciences, Master's Thesis no 82. Uppsala, Sweden.

Hart, P.B.S., Sparling, G.P., Kings, J.A., 1986. Relationship between mineralisable nitrogen and microbial biomass in a range of plant litters, peats, and soils of moderate to low pH. N. Z. J. Agric. Res. 29 (4), 681-686.

Heaton, T.H.E., 1986. Isotopic studies of nitrogen pollution in the hydrosphere and atmosphere: A review. Chem. Geol. 59 (1), 87-102.

Hinkle, S.R., Böhlke, J.K., Duff, J.H., Morgan, D.S., Weick, R.J., 2007. Aquifer-scale controls on the distribution of nitrate and ammonium in ground water near La Pine, Oregon, USA. J. Hydrolog. 333 (2-4), 486-503.

Hoefs, J., 1997. Stable isotope geochemistry. Springer-Verlag, Berlin.

Hung, C.V., Cam, B.D., Mai, P.T.N., Dzung, B.Q., 2015. Heavy metals and polycyclic aromatic hydrocarbons in municipal sewage sludge from a river in highly urbanized metropolitan area in Hanoi, Vietnam: levels, accumulation pattern and assessment of land application. Environ Geochem Health 37, 133146.

Huong, N.T.L., Ohtsubo, M., Li, L., Higashi, T., Kanayama, M., 2008. Assessment of the water quality of two rivers in Hanoi City and its suitability for irrigation water. Paddy Water Environ. 6 (3), 257-262.

Jiao, J. J., Wang, Y., Cherry, J. A., Wang, X., Zhi, B., Du, H., Wen, D., 2010. Abnormally High Ammonium of Natural Origin in a Coastal Aquifer-Aquitard System in the Pearl River Delta, China. Environ. Sci. Technol. 44(19), 7470-7475.

Jusseret, S., Baeteman, C., Dassargues, A., 2010. The stratigraphical architecture of the quaternary deposits as support for hydrogeological modelling of the central zone of Hanoi (Vietnam). Geol. Belg. 13 (1-2), 77-90.

Kendall, C., Aravena, R., 2000. Nitrate isotopes in groundwater systems. In: Cook, P.G., Herczeg, A.L. (Eds.), Environmental Tracers in Subsurface Hydrology. Kluwer Academic Publishers, Norwell, Massachusetts, pp. 261-297.

Kuroda, K., Nakada, N., Hanamoto, S., Inaba, M., Katayama, H., Do, A. T., Nga, T. T. V., Oguma, K., Hayashi, T., Takizawa, S., 2015. Pepper mild mottle virus as an indicator and a tracer of fecal pollution in water environments: Comparative evaluation with wastewater-tracer pharmaceuticals in Hanoi, Vietnam, Sci. Tot. Environ. 506-507, 287-298.

Larsen, F., Pham, N.Q., Dang, N.D., Postma, D., Jessen, S., Pham, V.H., Nguyen, T.B., Trieu, H.D., Tran, L.T., Nguyen, H., Chambon, J., Nguyen, H.V., Ha, D.H., Hue, N.T., Duc, M.T., Refsgaard, J.C., 2008. Controlling geological and hydrogeological processes in an arsenic contaminated aquifer on the Red River flood plain, Vietnam. Appl. Geochem. 23, 3099-3115.

Li, L., Lollar, B.S., Li, H., Wortmann, U.G., Lacrampe-Couloume, G., 2012. Ammonium stability and nitrogen isotope fractionations for $\mathrm{NH}_{4}{ }^{+}-\mathrm{NH}_{3 \text { (aq) }} \mathrm{NH}_{3 \text { (gas) }}$ systems at $20-70^{\circ} \mathrm{C}$ and $\mathrm{pH}$ of 2-13: Applications to habitability and nitrogen cycling in low-temperature hydrothermal systems. Geochim. Cosmochim. Acta 84, 280-296.

Moreskog, J., 2007. Investigation of the redox-conditions in the Nam Du well field, Hanoi, Vietnam, and their implications for mobilisation of arsenic. Swedish University of Agricultural Sciences, Department of Soil Sciences, Bachelor's Thesis no 83. Uppsala, Sweden.

Marcussen, H., Dalsgaard, A., Holm, P.E., 2008. Content, distribution and fate of 33 elements in sediments of rivers receiving wastewater in Hanoi, Vietnam. Environ. Pollut. 155 (1), 41-51.

Mayer, B., Boyer, E.W., Goodale, C., Jaworski, N.A., Van Breemen, N., Howarth, R.W., Seitzinger, S., Billen, G., Lajtha, K., Nadelhoffer, K., Van Dam, D., Hetling, L.J., Nosal, M., Paustian, K., 2002. Sources of nitrate in rivers draining sixteen watersheds in the northeastern U.S.: Isotopic constraints. Biogeochem. 57-58, 171-197.

Mengis, M., Walther, U., Bernasconi, S.M., Wehrli, B., 2001. Limitations of using $\delta 18 \mathrm{O}$ for the source identification of nitrate in agricultural soils. Environ. Sci. Technol. 35 (9), 1840-1844.

Norrman, J., Sparrenbom, C.J., Berg, M., Nhan, D.D., Nhan, P.Q., Rosqvist, H., Jacks, G., Sigvardsson, E., Baric, D., Moreskog, J., Harms-Ringdahl, P., Van Hoan, N., 2008. Arsenic mobilisation in a new well field for drinking water production along the Red River, Nam Du, Hanoi. Appl. Geochem. 23, 3127-3142. 
Ozaki, H., Co, T.K., Le, A.K., Pham, V.N., Nguyen, V.B., Tarao, M., Nguyen, H.C., Le, V.D., Nguyen, H.T., Sagehashi, M., Ninomiya-Lim, S., Gomi, T., Hosomi, M., Takada, H., 2014. Human factors and tidal influences on water quality of an urban river in Can Tho, a major city of the Mekong Delta, Vietnam. Environ. Monit. Assess. 186 (2), 845-858.

Postma, D., Larsen, F., Hue, N.T.M., Duc, M.T., Viet, P.H., Nhan, P.Q., Jessen, S., 2007. Arsenic in groundwater of the Red River floodplain, Vietnam: Controlling geochemical processes and reactive transport modeling. Geochim. Cosmochim. Acta 71 (21), 5054-5071.

QCVN 01:2009/BYT, 2009. National Technical Regulation on drinking water quality. Ministry of Health Care of Vietnam (in Vietnamese).

Schramm, S., 2011. Semicentralised water supply and treatment: Options for the dynamic urban area of Hanoi, Vietnam. J. Env. Assmt. Pol. Mgmt. 13 (2), 285-314.

Seitzinger, P.S., G.W.S., Spratt, K.A., 1991. The effect of salinity on ammonium sorption in aquatic sediments: Implications for benthic nutrient recycling. Estuaries 14 (2), 167-174.

Stenberg, B., Johansson, M., Pell, M., Sjödahl-Svensson, K., Stenström, J., Torstensson, L., 1998. Microbial biomass and activities in soil as affected by frozen and cold storage. Soil Biol. Biochem. 30 (3), 393 402.

Tanabe, S., Hori, K., Saito, Y., Haruyama, S., Van Phai, V., Kitamura, A., 2003a. Song Hong (Red River) delta evolution related to millenium-scale Holocene sea-level changes. Quat. Sci. Rev. 22, 2345-2361.

Tanabe, S., Hori, K., Saito, Y., Haruyama, S., Doanh, L.Q., Sato, Y., Hiraide, S., 2003b. Sedimentary facies and radiocarbon dates of the Nam Dinh-1 core from the Song Hong (Red River) delta, Vietnam. J. Asian Earth Sci. 21, 503-513.

Tanabe, S., Saito, Y., Vu, Q.L., Hanebuth, T.J.J., Ngo, Q.L., Kitamura, A., 2006. Holocene evolution of the Song Hong (Red River) delta system, northern Vietnam. Sediment. Geol. 187, 29-61.

Trafford, J.M., Lawrence, A.R., Macdonald, D.M.J., Nguyen Van Dan, Tran, D.N., Ha, N.T., 1996. The effect of urbanisation on the groundwater quality beneath the city of Hanoi. Technical Report WC/96/22, British Geological Survey, Keyworth, Nottingham, UK.

Tran, M., 1990. Report on the groundwater resources of Hanoi area, The Socialist Republic of Vietnam General Department of mines and geology, Hydrogeological division No 2, Chi Linh, Hanoi.

Van, N.K., Nhien, D.D., On, D.H., Anh, N.N., 1996. On the feasibility study for groundwater exploitation of Nam Du Thuong well field with capacity $30,000 \mathrm{~m}^{3} / \mathrm{d}$, (phase II), Ministry of construction, Union of Survey Companies, Construction Survey Enterprise No 1, Hanoi.

van Geen, A., Bostick, B.C., Trang, P.T.K., Lan, V.M., Mai, N.N., Manh, P.D., Viet, P.H., Radloff, K., Aziz, Z., Mey, J.L., Stahl, M.O., Harvey, C.F., Oates, P., Weinman, B., Stengel, C., Frei, F., Kipfer, R., Berg, M., 2013. Retardation of arsenic transport through a Pleistocene aquifer. Nature 501, 204-207.

Wang, Y., Jiao, J. J., Cherry, J. A., Lee, C. M., 2013. Contribution of the aquitard to the regional groundwater hydrochemistry of the underlying confined aquifer in the Pearl River Delta, China. Sci. Tot. Env. 461-462 (2013), 663-671.

WHO, 2003. Ammonia in drinking-water: Background document for preparation of WHO Guidelines for drinking-water quality. Geneva, World Health Organization (WHO/SDE/WSH/03.04/1).

Widory, D., Kloppmann, W., Chery, L., Bonnin, J., Rochdi, H., Guinamant, J.-L., 2004. Nitrate in groundwater: An isotopic multi-tracer approach. J. Contam. Hydrol. 72 (1-4), 165-188.

Winkel, L.H.E., Trang, P.T.K., Lan, V.M., Stengel, C., Amini, M., Ha, N.T., Viet, P.H., Berg, M., 2011. Arsenic pollution of groundwater in Vietnam exacerbated by deep aquifer exploitation for more than a century. Proceedings of the National Academy of Sciences of the United States of America, 108 (4), 1246-1251. 
${ }^{15} \mathrm{~N}$ isotope enrichment of ammonium from reducing aquifers due to deprotonation and degassing of ${ }^{14} \mathrm{NH}_{3}(g)$.

${ }^{15} \mathrm{~N}$ enrichment
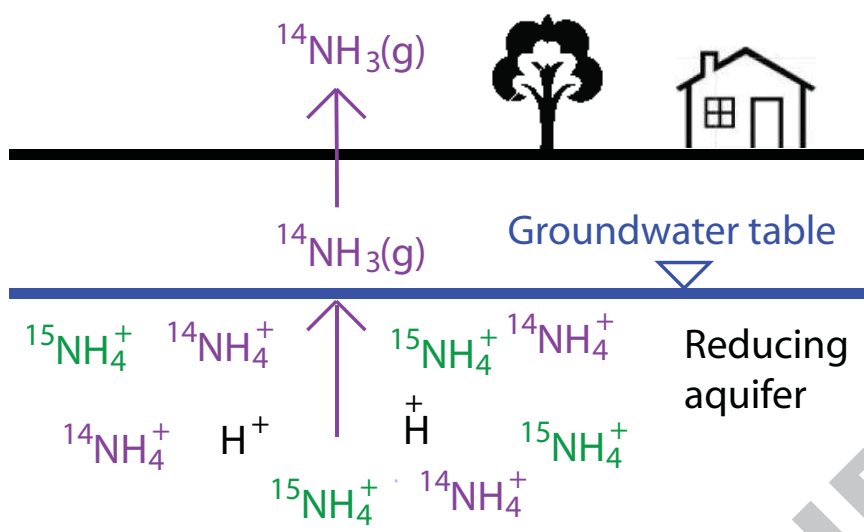